\title{
A crop model-based approach for sunflower yields
}

\author{
João Guilherme Dal Belo Leite ${ }^{1,2 *}$, João Vasco Silva ${ }^{1}$, Flávio Barbosa Justino², Martin K. van Ittersum ${ }^{1}$
}

${ }^{1}$ Wageningen University - Plant Production Systems Group, P.O. Box 430 - 6700 AK Wageningen - The Netherlands. 2Federal University of Viçosa - Agricultural Engineering Dept., Av. P.H. Rolfs, s/n - Campus Universitário - 36570000 - Viçosa, MG - Brazil.

*Corresponding author <dalbeloleite@yahoo.com.br>

Edited by: Paulo Cesar Sentelhas

Received October 25, 2013

Accepted March 08, 2014
ABSTRACT: Pushed by the Brazilian biodiesel policy, sunflower (Helianthus annuus L.) production is becoming increasingly regarded as an option to boost farmers' income, particularly under semi-arid conditions. Biodiesel related opportunities increase the demand for decision-making information at different levels, which could be met by simulation models. This study aimed to evaluate the performance of the crop model OILCROP-SUN to simulate sunflower development and growth under Brazilian conditions and to explore sunflower water- and nitrogen-limited, water-limited and potential yield and yield variability over an array of sowing dates in the northern region of the state of Minas Gerais, Brazil. For model calibration, an experiment was conducted in which two sunflower genotypes (H358 and E122) were cultivated in a clayey soil. Growth components (leaf area index, above ground biomass, grain yield) and development stages (crop phenology) were measured. A database composed of 27 sunflower experiments from five Brazilian regions was used for model evaluation. The spatial yield distribution of sunflower was mapped using ordinary kriging in ArcGIS. The model simulated sunflower grain productivity satisfactorily (Root Mean Square Error $\approx 13 \%$ ). Simulated yields were relatively high (1,750 to 4,250 $\mathrm{kg} \mathrm{ha}^{-1}$ ) and the sowing window was fairly wide (Oct to Feb) for northwestern locations, where sunflower could be cultivated as a second crop (double cropping) at the end of the rainy season. The hybrid $\mathrm{H} 358$ had higher yields for all simulated sowing dates, growth conditions and selected locations. Keywords: production systems, family farms, biodiesel crops, climate classification

\section{Introduction}

Launched in 2004, the biodiesel policy is a recent attempt to combine renewable energy with rural development in Brazil. This policy aims at boosting rural income through the engagement of family farmers as biodiesel crop producers. Government research and extension agencies together with the energy sector, i.e. Petrobras (Brazilian energy company), are keen to implement projects able to foster biodiesel crop production. Sunflower (Helianthus aпnuиs L.) has been considered a promising alternative for family farming systems, particularly in the semi-arid regions of the country. The northern region of the state of Minas Gerais is of particular interest due to its potential for sunflower cultivation, diversity of climatic zones and farming systems (Leite et al., 2013).

The interest in biodiesel crops has also created an increasing demand for supportive knowledge for agricultural decision-making at different levels, which traditional agronomic research through field experimentation (expensive and time consuming) often fails to meet (Jones et al., 2003). Crop growth simulation models are a useful tool to explore and simulate cropping systems and to enhance understanding of their performance under different growth conditions. Furthermore, the system approach imbibed in such models can help to better target empirical studies thus setting an agenda for experimental research (Bouman et al., 1996; Ittersum et al., 2003).

Although empirical research on the eco-physiological aspects of sunflower growth has been documented quite extensively (Goyne and Schneiter, 1988; Hall et al.,
1989; Hall et al., 1995; Pereira et al., 1999; Robinson, 1971; Sadras et al., 1988; Sadras and Hall, 1993; Trapani et al., 1992; Villalobos and Ritchie, 1992), the number of modelling-oriented studies aiming to explore crop management strategies such as irrigation, sowing dates and yield variability is as yet limited (Rinaldi et al., 2003; Todorovic et al., 2009).

This study evaluated the performance of the crop model OILCROP-SUN for the simulation of sunflower phenology and growth components such as leaf area index, above ground biomass and grain yield under Brazilian conditions and to explore sunflower yield, and its variability, over an array of sowing dates in the northern region of Minas Gerais, Brazil. Such analysis also aims to create awareness of the suitability of crop growth simulation models and to gain knowledge of crop management strategies associated with single and double cropping systems.

\section{Materials and Methods}

\section{Model overview}

OILCROP-SUN is a process-oriented crop model which simulates, with a daily time step, sunflower development and growth (Villalobos et al., 1996). It is a CERES-type model which belongs to the Decision Support System for Agro-technology Transfer (DSSAT). DSSAT provides a framework for cropping system analysis whereby different crop models can be built into a platform with compatible input files, data structure and modes of operation (IBSNAT, 1993; Jones et al., 2003). In this study OILCROP-SUN v3.5 and DSSAT v4.5 were used. 
Crop development is divided into three phases: (i) sowing to emergence; (ii) emergence to first anthesis; and (iii) first anthesis to physiological maturity. Cumulative thermal time regulates the duration of each phase (Robinson, 1971), while the photoperiod only interferes with the flower bud initiation (e.g. Goyne and Schneiter, 1988). For the calculation of the cumulative thermal time, a base temperature of $4{ }^{\circ} \mathrm{C}$ is considered (Villalobos and Ritchie, 1992). In OILCROP-SUN, crop development is regulated by three genotype-specific genetic coefficients (P1, P2 and P5). P1 expresses the length of the juvenile phase in ${ }^{\circ} \mathrm{C}$ day. P2 is a photoperiodic coefficient that identifies the number of days by which development is delayed when the crop is grown in a photoperiod shorter than the optimum (15 h) and is expressed in days per hour of shorter photoperiod (days $\mathrm{h}^{-1}$ ). P5 accounts for the duration of the first anthesis to the physiological maturity stage expressed in ${ }^{\circ} \mathrm{C}$ day. Leaf appearance, expansion and senescence are used to estimate leaf area index (LAI) during the growing period and are modelled as a function of temperature as well (Villalobos et al., 1996).

Photosynthesis is modelled based on the concept of radiation use efficiency (RUE), i.e. the rate of conversion of intercepted radiation into new biomass, which varies with crop development (Trapani et al., 1992). Biomass accumulation over time is reduced by the most constraining factors, namely temperature, water or nitrogen, and biomass is partitioned among the growing organs by means of partitioning coefficients. Finally, sunflower yield is computed by the product of grain number, grain weight and plant population. Plant population is experimentally defined, whereas grain number and weight are controlled by three genotype-specific genetic coefficients $(\mathrm{G} 2, \mathrm{G} 3$ and O1). G2 is the maximum number of grains per capitulum. Grain weight varies with the length of the grain filling phase (P5) and grain growth rate that is controlled by the genetic coefficient G3 (potential kernel growth rate) is expressed in $\mathrm{mg}$ day $^{-1}$. Grain oil content is represented by the genetic coefficient $\mathrm{O} 1$ that defines the maximum kernel oil content $(\%)$.

\section{Model calibration}

A field experiment was conducted in Viçosa $\left(20.76^{\circ}\right.$ $\mathrm{S}, 42.86^{\circ} \mathrm{W}, 712 \mathrm{~m}$ altitude), in the southeast of the state of Minas Gerais, Brazil. The experiment was sown on $25^{\text {th }}$ Nov 2011 in a clayey Ultisol (US soil taxonomy) under rain nurtured conditions, covering an area of $400 \mathrm{~m}^{2}$. Two treatments were applied corresponding to two genotypes, Embrapa 122 (E122, conventional cultivar) and Helio 358 (H358, hybrid), currently being tested and cultivated for biodiesel production in the north of Minas Gerais.

Each treatment was sown over an area of $200 \mathrm{~m}^{2}$ which was split into four replications of $50 \mathrm{~m}^{2}(5 \times 10 \mathrm{~m})$ each. The experiment was set in a randomized block design (four replications = four blocks) containing, in each block, one replication of each genotype. Plant population at sowing was 5 plants $\mathrm{m}^{-2}$, corresponding to a spacing of $0.7 \times 0.285 \mathrm{~m}$. The supply of macro-nutrients was calculated based on soil analysis and expected yields and was split into two applications of mineral fertiliser. The first occurred at the sowing in which 16, 56 and $32 \mathrm{~kg}$ ha $^{-1}$ of $\mathrm{N}$ (urea), P (triple superphosphate) and $\mathrm{K}$ (potassium chloride) were applied. The second was performed 21 days after emergence when 120, 30 and $120 \mathrm{~kg} \mathrm{ha}^{-1}$ of $\mathrm{N}, \mathrm{P}$ and $\mathrm{K}$ were applied.

At physiological maturity, which was registered on $6^{\text {th }}$ and $12^{\text {th }}$ Mar 2012 for E122 and H358, respectively, sunflower grain yield was estimated based on destructive sampling of 40 sunflower plants per genotype. Crop phenology was registered every five days, following the scale suggested by Schneiter and Miller (1981). LAI and above-ground biomass were measured seven times throughout the growing period from a sample of 20 sunflower plants per genotype to evaluate the capability of the model to reproduce the observed values and patterns. LAI was estimated based on the relationship between leaf area and leaf weight (specific leaf area; in $\mathrm{cm}^{2}$ ) of 10 leaves in each plant randomly selected throughout the stem. For quantifying above-ground dry biomass, the entire aerial part, i.e. stem, petiole, leaves, bracts and capitulum, of the sampled plants in each period were oven dried $\left(65 \pm 5^{\circ} \mathrm{C}\right)$ to constant weight.

In addition to experimental data, weather data and soil profile information were used as inputs to calibrate OILCROP-SUN for the genotypes studied. Maximum and minimum air temperature, solar radiation and precipitation are required to run DSSAT (Hoogenboom, 2000) and were obtained from a conventional weather station located about $2 \mathrm{~km}$ from the experimental area. Solar radiation values were estimated following the methodology presented by Allen et al. (1998). Information about soil texture and soil organic carbon throughout the soil profile of the experimental site was obtained from Rodrigues et al. (2013).

The calibration of OILCROP-SUN consisted of the estimation of the six genotype-specific genetic coefficients for E122 and H358, which was done manually and following a step-by-step approach. The development coefficients P1, P2 and P5 were calibrated by adjusting the simulated first anthesis and physiological maturity dates to the observed ones. Afterwards, the yield coefficients G2, G3 and O1 were adjusted taking into consideration literature reference values (Villalobos et al., 1996; Rinaldi et al., 2003).

To evaluate the accuracy between model simulations and observed experimental values during the calibration process the percentage of absolute deviation (PAD) was used. PAD is defined as the absolute deviation between simulated and observed values. Similarly, according to Hazell and Norton (1986), it is assumed that a satisfactory calibration is achieved when PAD values $\leq$ $15 \%$. PAD was estimated as follows:

$P A D(\%)=100 \times \frac{\left(\sum_{i}\left|P_{i}-O_{i}\right|\right)}{\sum_{i} O_{i}}$

where: $O_{i}$ stands for observed values and $P_{i}$ for simulated values. 


\section{Climatological classification}

Climatological classification is an important step in improving the selected modelling approach through the combination of knowledge of weather and soil elements with crop growth and phenological components. Ultimately, it allows for a better understanding of the plant-climate relationship (Thornthwaite, 1948) and its consequences on simulation outcomes.

A climatological description of all locations explored in this study is presented in Table 1 . For each weather station daily mean temperature and rainfall data from 2000 to 2009 were collected (INMET, 2012). Using this information the climatological classification of Thornthwaite (1948) was applied. This approach is underpinned by the regional water balance in which differences in soil characteristics were taken into account. The soil water holding capacity (SWHC) is an important component of the water balance and is defined based on soil texture and rooting depth of sunflower. SWHC was estimated according to the following equation:

$S W H C(m m)=S W H C \mu \times Z r$

in which $S W H C \mu$ is the average value of SWHC, given in $\mathrm{mm}$ of water per $\mathrm{cm}$ of clay, loamy or sandy soils (Doorenbos and Kassmam, 1994); and $Z r$ is the depth $(\mathrm{cm})$ of the rooting system. The calculated values of SWHC used in this study were 100, 70 and 30 for clay, loamy and sandy soils, respectively.

\section{Model evaluation}

Data from field experiments conducted in the states of Minas Gerais, Goiás, São Paulo, Paraná and Distrito Federal between 2004 - 2011 with the genotypes E122 and H358 were used to test the performance of the model to simulate sunflower yield and phenol-

Table 1 - Weather station coordinates, climate classification and experimental information (genotype and year) for the locations studied during the calibration, evaluation and application phases.

\begin{tabular}{|c|c|c|c|c|c|}
\hline \multirow{2}{*}{ Location (state) } & \multicolumn{3}{|c|}{ Weather station coordinates } & \multirow{2}{*}{$\begin{array}{l}\text { Climate classification: Thornthwaite } \\
(1948)^{*}\end{array}$} & \multirow{2}{*}{ Genotype (year) } \\
\hline & Lat $\left({ }^{\circ}\right)$ & Long $\left({ }^{\circ}\right)$ & Alt (m) & & \\
\hline Calibration & & & & & \\
\hline Viçosa (MG) & -20.76 & -42.86 & 712 & B4wB'3a' & H358; E122 (2011) \\
\hline \multicolumn{6}{|l|}{ Validation } \\
\hline Londrina (PR) & -23.31 & -51.13 & 566 & B2rB'4a' & $\begin{array}{l}\text { E122 (2004; 2005;2008) } \\
\text { H358 (2008; 2009; 2010) }\end{array}$ \\
\hline Cravinhos (SP) & -21.48 & -47.55 & 617 & B4wA'a' & $\begin{array}{l}\text { E122 }(2005 ; 2006) \\
\text { H358 (2009) }\end{array}$ \\
\hline Planaltina (DF) & -16.00 & -47.33 & 1033 & B1w2A'a' & $\begin{array}{l}\text { E122 (2005; 2006; 2009) } \\
\text { H358 (2008; 2009; 2011) }\end{array}$ \\
\hline Piracicaba (SP) & -22.70 & -47.63 & 546 & B1rB'4a' & E122 (2006) \\
\hline Jaíba (MG) & -15.80 & -43.29 & 516 & DwA'a' & E122; H358 (2007) \\
\hline Jaguariúna (SP) & -22.70 & -47.63 & 546 & B1rB'4a' & E122 (2008) \\
\hline Patos de Minas (MG) & -18.51 & -46.43 & 940 & Aw2B'4a' & H358 (2008; 2009) \\
\hline Leme do Prado (MG) & -16.83 & -42.05 & 289 & C1dA'a' & $\begin{array}{l}\mathrm{H} 358(2008) \\
\mathrm{E} 122(2010)\end{array}$ \\
\hline Rio Verde (GO) & -17.80 & -50.91 & 774 & B4w2A'a' & H358 (2008) \\
\hline Uberaba (MG) & -19.73 & -47.95 & 737 & AwA'a' & H358 (2008) \\
\hline Janaúba (MG) & -15.80 & -43.29 & 516 & DwA'a' & H358 (2009) \\
\hline Patrocínio (MG) & -18.51 & -46.43 & 940 & Aw2B'4a' & H358 (2009) \\
\hline \multicolumn{6}{|l|}{ Application } \\
\hline Araçuaí (MG) & -16.83 & -42.05 & 289 & C1dA'a' & E122; H358 (1979 to 2009) \\
\hline Arinos (MG) & -15.91 & -46.10 & 519 & C2w2A'a' & E122; H358 (1979 to 2009) \\
\hline Espinosa (MG) & -14.91 & -42.80 & 569 & DdA'a' & E122; H358 (1979 to 2009) \\
\hline Formoso (MG) & -14.93 & -46.25 & 840 & B1w2A'a' & E122; H358 (1979 to 2009) \\
\hline Itamarandiba (MG) & -17.85 & -42.85 & 914 & B2w2B'3a' & E122; H358 (1979 to 2009) \\
\hline João Pinheiro & -17.73 & -46.17 & 760 & B2w2A'a' & E122; H358 (1979 to 2009) \\
\hline Janaúba (MG) & -15.80 & -43.29 & 516 & DwA'a' & E122; H358 (1979 to 2009) \\
\hline Januária (MG) & -15.45 & -44.00 & 473 & C1w2A'a' & E122; H358 (1979 to 2009) \\
\hline Montes Claros (MG) & -16.68 & -43.84 & 652 & C2w2A'a' & E122; H358 (1979 to 2009) \\
\hline Pedra Azul (MG) & -16.00 & -41.28 & 649 & C1w2A'a' & E122; H358 (1979 to 2009) \\
\hline Paracatu (MG) & -17.24 & -46.88 & 712 & B4w2A'a' & E122; H358 (1979 to 2009) \\
\hline Pirapora (MG) & -17.35 & -44.91 & 505 & C1w2A'a' & E122; H358 (1979 to 2009) \\
\hline Salinas (MG) & -16.15 & -42.28 & 471 & DdA'a' & E122; H358 (1979 to 2009) \\
\hline Unaí (MG) & -16.36 & -46.88 & 460 & B1w2A'a' & E122; H358 (1979 to 2009) \\
\hline
\end{tabular}

${ }^{*}$ For more information on the climate classification (acronyms), please see Figure 4. 
ogy. The source of sustenance for all experiments was rainfall, although some benefited from supplementary irrigation in cases of extreme drought. For each experimental site, weather data was obtained from conventional weather stations in the $5^{\text {th }}$ Meteorological District of the National Institute of Meteorology (INMET; Table 1). Due to lack of more detailed weather data, a zone with $100 \mathrm{~km}$ radius around the weather station was considered as a climatically homogeneous area. In each experimental location, information on soil organic carbon (Org. C.) and texture throughout the soil profile were gathered from the literature (Jacomine et al., 1979; IBGE, 1986).

A computer simulation experiment was created with OILCROP-SUN, for each experiment. The evaluation process consisted of model-runs with the previously calibrated genetic coefficients under different experimental and environmental conditions, i.e. model results were compared with independent datasets. The model evaluation (Jamieson et al., 1991; Loague and Green, 1991) was performed using two statistical indexes, namely Root Mean Square Error (RMSE) and Modelling Efficiency (ME), as described by Rinaldi et al. (2003):

$$
\begin{aligned}
& R M S E=\sqrt{\frac{\sum_{i=i}^{n}\left(P_{i}-O_{i}\right)^{2}}{n} \cdot \frac{100}{0}} \\
& M E=\frac{\left[\sum_{i=1}^{n}\left(O_{i}-O\right)^{2}-\sum_{i=1}^{n}\left(P_{i}-O_{i}\right)^{2}\right]}{\sum_{i=1}^{n}\left(O_{i}-O\right)^{2}}
\end{aligned}
$$

where: $P i$ stands for the predicted values, $O i$ for the observed values and $O$ for the observed mean values. RMSE measures the difference between simulated and observed data. Simulations are considered to be excellent with RMSE < $10 \%$, good between 10-20\%, fair between 20-30\%, and poor > $30 \%$. The lower limit for both RMSE and ME is zero. The maximum value for $\mathrm{ME}$ is 1 . If $\mathrm{ME}$ is less than zero the simulated values are worse than simply using the observed mean values. A positive value for $\mathrm{ME}$, on the other hand, indicates that the model performs better than simply applying the observed mean (Loague and Green, 1991).

\section{Model application}

OILCROP-SUN was used to simulate yields of the two sunflower genotypes, E122 and H358, in 14 locations in the northern region of Minas Gerais (Figure 1). Weather data for the period 1979 - 2009 (31 years; INMET, 2012) were used to study the inter-annual variability of sunflower yield under potential, water-limited and water- and nitrogen-limited growth conditions for all locations. Different growth conditions can be implemented in OILCROP-SUN by turning 'off' or 'on' the soil-nitrogen and/or the soil-water subroutines in the model. Simulations were performed on 32 sowing dates, with a weekly time step, between the end of Aug and the end of Mar to explore optimal sowing periods for sunflower across the region studied.

A different soil profile was used for each of the locations studied in northern Minas Gerais (Table 2). The selection of soils was based on their geographical and physical (texture) characteristics. Under this approach the selected profile should be both close to a particular location and share similar regional soil properties (Figure 2).

An application of $75 \mathrm{~kg}$ of N, $15 \mathrm{~kg}$ at sowing and $60 \mathrm{~kg} 30$ days after sowing, was used as the standard fertilizer management strategy exclusively for water- and nitrogen-limiting simulations. Such nutrient management is based on the most common farmers' practices and information in the literature. Additional water supply through irrigation was not considered. For water-limited simulations, fertilizer inputs were not considered as the soil-nitrogen sub-routine was switched 'off'.

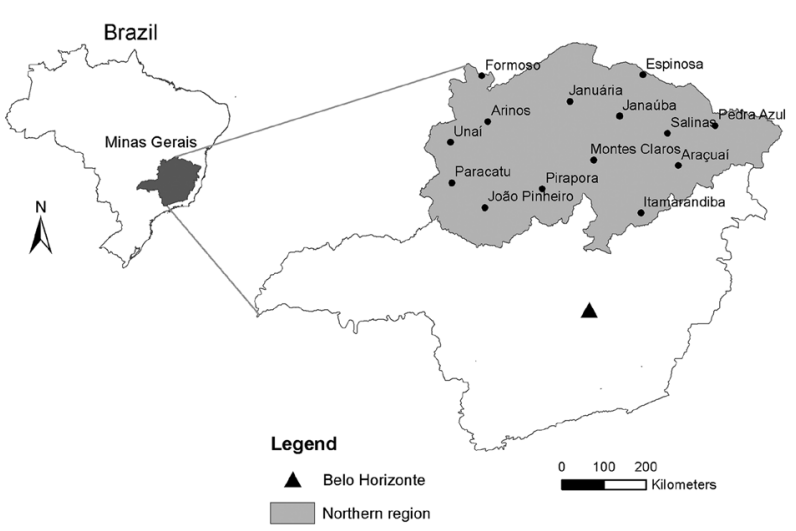

Figure 1 - Locations in the northern region of the state of Minas Gerais, Brazil used for crop model simulations.

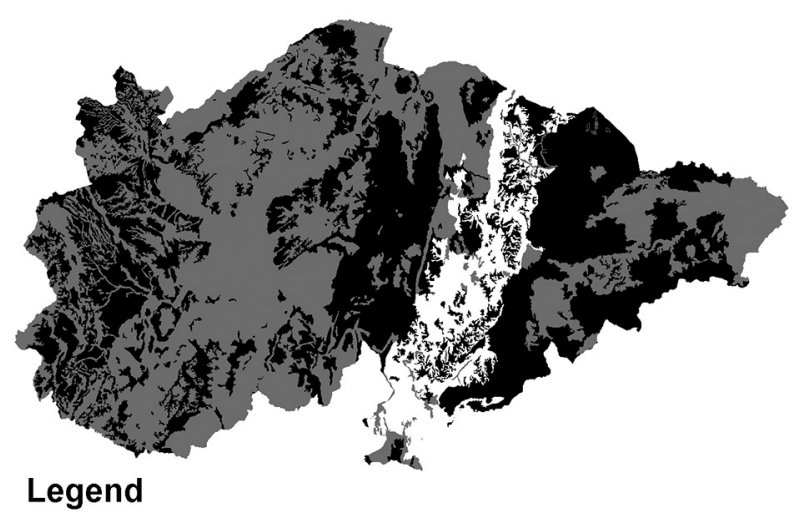

Soil texture

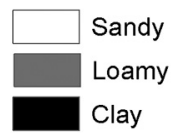

Figure 2 - Soil texture across the northern region of the state of Minas Gerais, Brazil. Source: Universidade Federal de Viçosa et al. (2010). 
Table 2 - Selected soil profiles for each studied location.

\begin{tabular}{|c|c|c|c|c|c|c|c|}
\hline \multirow{2}{*}{$\begin{array}{l}\text { Location } \\
\text { (state) }\end{array}$} & \multicolumn{2}{|c|}{$\begin{array}{c}\text { Soil profile } \\
\text { coordinates }\end{array}$} & \multirow{2}{*}{ Depth* } & \multicolumn{3}{|c|}{ Texture } & \multirow{2}{*}{ Org. C } \\
\hline & Lat $\left(^{\circ}\right)$ & Long $\left({ }^{\circ}\right)$ & & Sand & Silt & Clay & \\
\hline & & & $\mathrm{m}$ & & & & \\
\hline \multirow[t]{3}{*}{ Araçuai (MG) } & -16.68 & -41.50 & 0.20 & 44 & 17 & 39 & 1.30 \\
\hline & & & 0.50 & 33 & 14 & 53 & 0.62 \\
\hline & & & 1.00 & 30 & 17 & 53 & 0.58 \\
\hline \multirow[t]{3}{*}{ Arinos (MG) } & -15.91 & -47.98 & 0.10 & 72 & 5 & 23 & 1.34 \\
\hline & & & 0.45 & 66 & 6 & 28 & 0.62 \\
\hline & & & 1.15 & 59 & 10 & 31 & 0.36 \\
\hline \multirow[t]{3}{*}{ Espinosa (MG) } & -14.98 & -42.23 & 0.28 & 67 & 6 & 27 & 0.68 \\
\hline & & & 0.52 & 59 & 5 & 36 & 0.49 \\
\hline & & & 0.94 & 46 & 7 & 47 & 0.38 \\
\hline \multirow[t]{3}{*}{ Formoso (MG) } & -14.68 & -46.83 & 0.20 & 64 & 5 & 31 & 0.70 \\
\hline & & & 0.50 & 51 & 8 & 41 & 0.36 \\
\hline & & & 1.00 & 63 & 7 & 40 & 0.20 \\
\hline \multirow{3}{*}{$\begin{array}{l}\text { Itamarandiba } \\
\text { (MG) }\end{array}$} & -17.90 & -42.41 & 0.25 & 34 & 10 & 56 & 1.16 \\
\hline & & & 0.45 & 31 & 7 & 62 & 0.78 \\
\hline & & & 0.75 & 28 & 7 & 65 & 0.51 \\
\hline \multirow[t]{3}{*}{ João Pinheiro } & -17.75 & -46.36 & 0.30 & 74 & 4 & 22 & 1.42 \\
\hline & & & 0.53 & 74 & 3 & 23 & 0.49 \\
\hline & & & 1.10 & 77 & 1 & 22 & 0.21 \\
\hline \multirow[t]{3}{*}{ Janaúba (MG) } & -15.80 & -43.29 & 0.20 & 67 & 10 & 23 & 0.34 \\
\hline & & & 0.60 & 66 & 9 & 25 & 0.13 \\
\hline & & & 0.90 & 69 & 9 & 22 & 0.27 \\
\hline \multirow[t]{3}{*}{ Januária (MG) } & -15.45 & -44.31 & 0.15 & 78 & 10 & 12 & 1.21 \\
\hline & & & 0.60 & 74 & 7 & 19 & 0.15 \\
\hline & & & 0.98 & 79 & 6 & 15 & 0.39 \\
\hline \multirow{3}{*}{$\begin{array}{l}\text { Montes Claros } \\
\text { (MG) }\end{array}$} & -16.37 & -44.08 & 0.16 & 45 & 1 & 54 & 2.07 \\
\hline & & & 0.42 & 37 & 1 & 62 & 1.24 \\
\hline & & & 0.74 & 33 & 1 & 66 & 0.66 \\
\hline \multirow[t]{2}{*}{ Pedra Azul (MG) } & )-16.03 & -40.42 & 0.18 & 53 & 8 & 39 & 0.69 \\
\hline & & & 1.30 & 44 & 6 & 50 & 0.62 \\
\hline \multirow[t]{3}{*}{ Paracatu (MG) } & -17.24 & -46.92 & 0.15 & 54 & 8 & 38 & 1.3 \\
\hline & & & 0.50 & 50 & 6 & 44 & 0.61 \\
\hline & & & 1.00 & 46 & 6 & 48 & 0.2 \\
\hline \multirow[t]{3}{*}{ Pirapora (MG) } & -17.33 & -44.80 & 0.10 & 50 & 34 & 16 & 1.52 \\
\hline & & & 0.38 & 59 & 28 & 13 & 0.54 \\
\hline & & & 0.75 & 63 & 23 & 14 & 0.15 \\
\hline \multirow[t]{2}{*}{ Salinas (MG) } & -16.16 & -42.20 & 0.20 & 61 & 10 & 29 & 0.95 \\
\hline & & & 1.20 & 48 & 8 & 44 & 0.54 \\
\hline \multirow[t]{2}{*}{ Unaí (MG) } & -16.21 & -46.00 & 0.25 & 57 & 8 & 35 & 1.07 \\
\hline & & & 1.00 & 49 & 13 & 38 & 0.57 \\
\hline
\end{tabular}

*Representative of the crop root system depth. Source: Jacomine et al. (1979); Radambrasil (1986).

The spatial distribution of sunflower water- and nitrogen-limited yield was assessed based on the average simulations over 31 years (1979 - 2009) for all selected locations in the northern region of Minas Gerais (Figure 1). Sunflower yield variability and the Thornthwaite (1948) climatological classification were then mapped using the ordinary 'kriging' method in ArcGIS 10, as described by Lu and Fan (2013); Pringle et al. (2004); and Vieira and Gonzalez (2003).

\section{Results and Discussion}

Model calibration: genetic coefficients, crop development and growth components

Genetic coefficient values for both H358 and E122 (Table 3) were within the reference range proposed by Villalobos et al. (1996). The exception was the G3 coefficient (potential kernel growth rate during the filling phase) for which the value obtained $(6.5$; Table 3$)$ is above the value suggested in the literature $(1.2-2.4)$. However, similarly high values of G3 were also found by Rinaldi et al. (2003) and might be associated with the relatively short cycle and high crop yields for modern sunflower genotypes.

The calibration procedure resulted in satisfactory (PAD $\leq 15 \%)$ agreement between the observed and simulated yields, date of first anthesis and physiological maturity. However, the model performed poorly in simulating LAI and above ground biomass for both genotypes, with PAD values higher than $15 \%$ (Table 4). Simulated

Table 3 - Calibrated genetic coefficients for the sunflower genotypes $\mathrm{E} 122$ and $\mathrm{H} 358$.

\begin{tabular}{|c|c|c|c|c|c|c|}
\hline Treatments & $\mathrm{P} 1$ & P2 & P5 & G2 & G3 & 01 \\
\hline E-122 & 260.0 & 1.30 & 715.0 & 1500 & 6.50 & 75 \\
\hline $\mathrm{H}-358$ & 305.0 & 0.90 & 790.0 & 1700 & 6.50 & 75 \\
\hline
\end{tabular}

Table 4 - Observed (Viçosa - MG) and simulated values for crop development (days after planting - DAP) and growth components (leaf are index, total aboveground dry matter biomass - DM and yield) of each genotype (E122 and H358) followed by the percentage of absolute deviation (PAD) obtained for model calibration.

\begin{tabular}{|c|c|c|c|c|}
\hline Genotype & Variable & Observed & Simulated & PAD (\%) \\
\hline \multirow[t]{5}{*}{ E122 } & First anthesis (DAP) & 61 & 61 & 0 \\
\hline & Physiological maturity (DAP) & 98 & 98 & 0 \\
\hline & Leaf area index & 2.6 & 1.5 & 42 \\
\hline & $\begin{array}{l}\text { Above ground biomass } \\
\left(\mathrm{kg} \mathrm{DM} \mathrm{ha}^{-1}\right)\end{array}$ & 6600 & 4700 & 29 \\
\hline & Yield $\left(\mathrm{kg} \mathrm{ha}^{-1}\right)$ & 3860 & 3940 & 2 \\
\hline \multirow[t]{5}{*}{ H358 } & First anthesis (DAP) & 67 & 67 & 0 \\
\hline & Physiological maturity (DAP) & 108 & 108 & 0 \\
\hline & Leaf area index $x^{a}$ & 4.3 & 2.1 & 51 \\
\hline & $\begin{array}{l}\text { Above ground biomass } \\
\left(\mathrm{kg} \mathrm{DM} \mathrm{ha}^{-1}\right)\end{array}$ & 9400 & 6500 & 31 \\
\hline & Yield $\left(\mathrm{kg} \mathrm{ha}^{-1}\right)$ & 5000 & 4890 & 2 \\
\hline
\end{tabular}

aAverage leaf area index during the growing season. Observed values correspond to the average of seven experimental measurements. Simulated values represent the average simulated LAl for the same dates when field observations were measured. 'Average above ground biomass during the growing season. Observed values correspond to the average of five experimental measurements. Simulated values represent the average simulated above ground biomass for the dates when field observations were measured. 
LAI and above ground biomass were always underestimated by OILCROP-SUN throughout the growing season (Figure 3). This might indicate a model limitation, as similar results were also found by Rinaldi et al. (2003).

In the OILCROP-SUN model, leaf area dynamics were indirectly adjusted in the calibration procedure of the genetic coefficient P1, which defines the length of the vegetative growth period. As there is no genetic coefficient for leaf area, it basically responds (indirectly) to the length of the vegetative phase defined by P1. Model performance could be improved particularly with regard to simulations of above ground biomass through the direct calibration of the leaf area dynamics, i.e. specific leaf area, LAI growth rate and assimilate partitioning. A similar approach was successfully implemented in different crop growth simulation models (Boogaard et al., 1998; Laar et al., 1997).
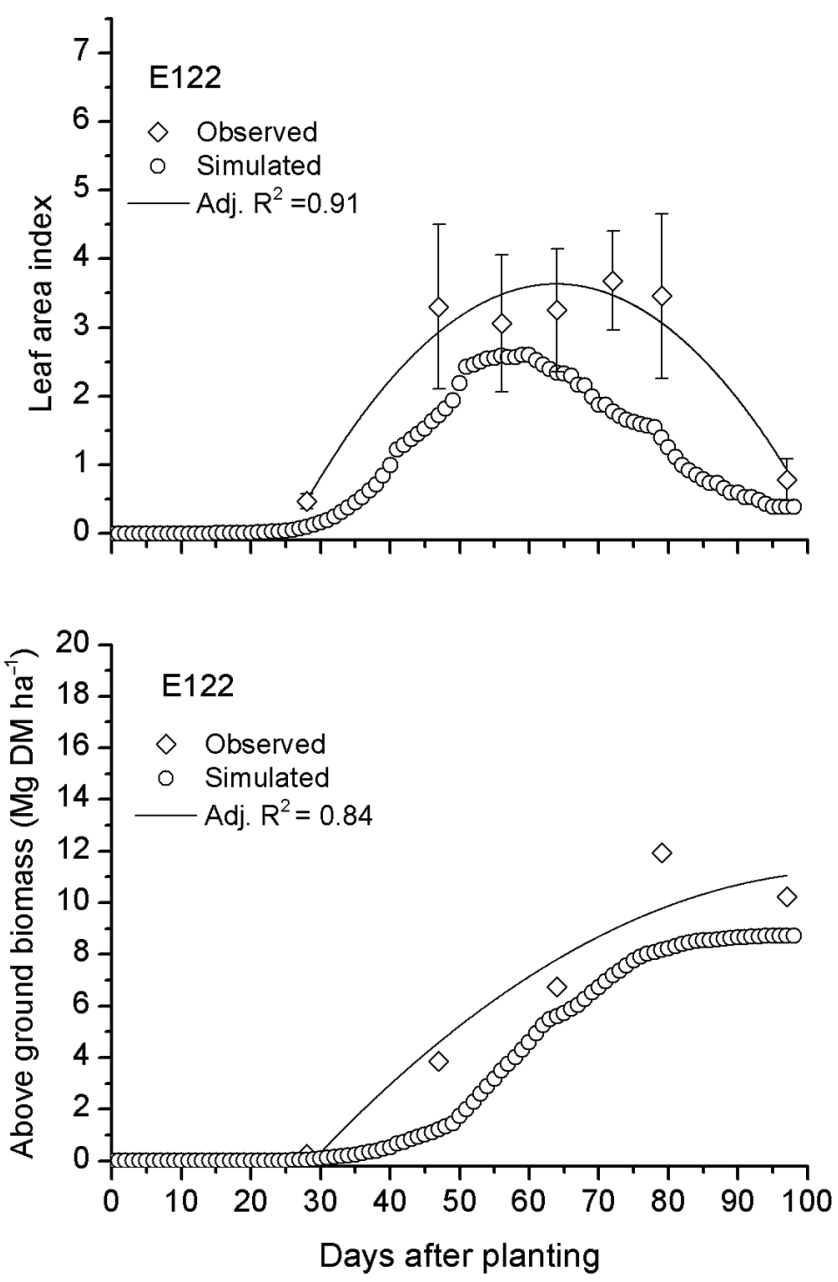

Consistent underestimation of LAI values was also found with the CERES-MAIZE model (Lizaso et al., 2003), which also belongs to the DSSAT framework. A new leaf area model to simulate expansion, longevity and senescence of maize (Zea mays L.) leaves was implemented resulting in enhanced model simulations. Such approach could be tested for OILCROP-SUN using whole-plant analysis to quantify sunflower leaf dynamics (e.g. Dosio et al., 2003). Although above ground biomass is partially determined by LAI (Whitfield et al., 1989), further modifications to the model radiation use, efficiency and harvest index parameters maybe needed to improve the quality of simulations for this growth component (Rinaldi et al., 2003).

The hybrid H358 had a longer growth cycle (108 days) than the conventional cultivar E122, with 98 days (Table 4). The longer cycle combined with greater LAI contributes to achieve higher yield and above ground
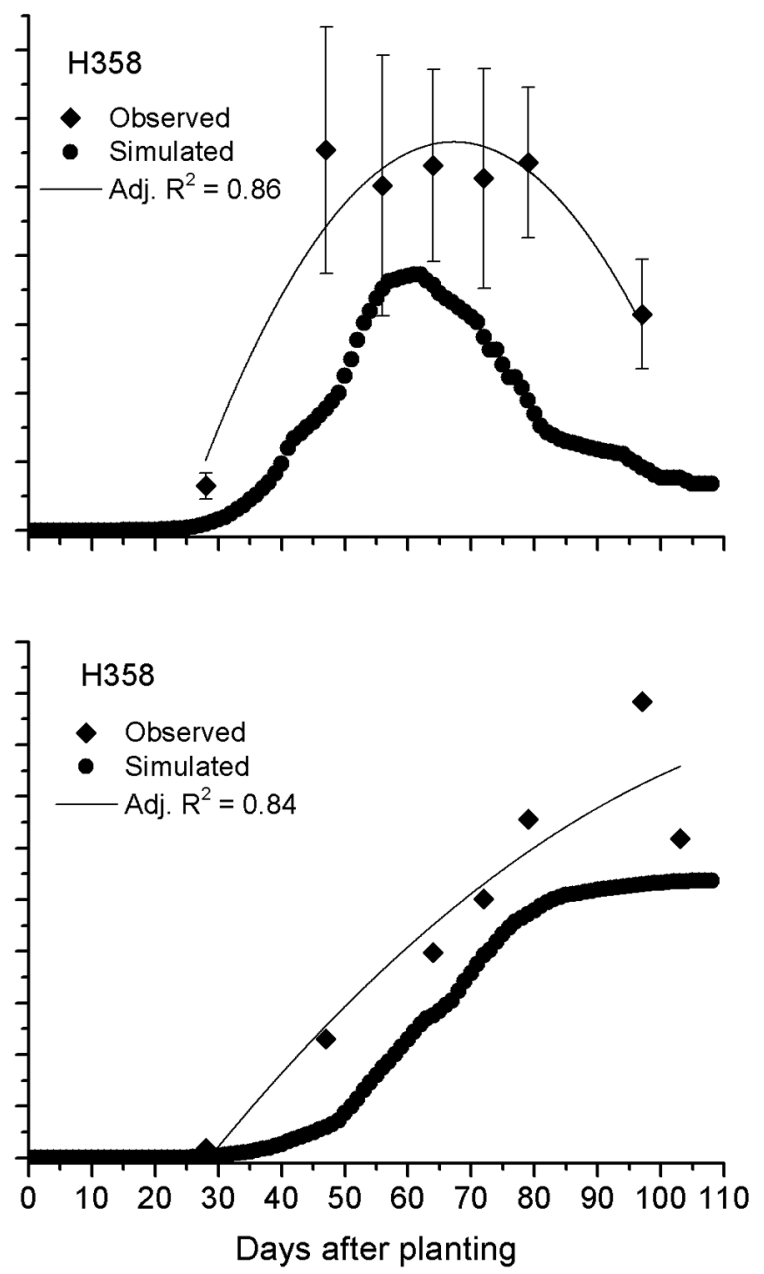

Figure 3 - Observed and simulated leaf area index (LAl) and above ground dry matter (DM) for both genotypes (E122 and H358) over the growing cycle (days after planting - DAP) under water- and nitrogen-limited conditions, in Viçosa, in the state of Minas Gerais, Brazil. Dots represent the averages $(n=20)$ and bars the standard deviations. The fitted curve is calculated from the observed experimental values. 
biomass production of H358. Moreover, the higher accumulation of assimilates from emergence to first anthesis makes a substantial contribution to sunflower grain filling at the end of the growing period (Hall et al., 1989).

\section{Model evaluation: statistical evaluation of model performance}

The model had good performance (RMSE between $10-20 \%$ and $\mathrm{ME}>0$ ) in simulating sunflower yields for both genotypes according to the statistical indicators selected (Table 5). Crop phenology, on the other hand, was poorly simulated by the model. The negative values for ME are an indication of the unreliability of the simulated values of first anthesis and physiological maturity (Table 5).

The poor quality $(\mathrm{ME}<0)$ of the simulated sunflower phenology might have been affected by inherited uncertainty associated with the observed experimental values. Across the experiments used to evaluate the model, crop development was observed by experimentalists, thus creating potential imprecision as there is often no consensus on how to identify, for instance, whether sunflower plants have achieved physiological maturity (Connor and Sadras, 1992). Grain yield estimation, on the other hand, is less vulnerable to variation in the measurement standards, and can thus reduce the uncertainty associated with experimental observations.

\section{Regional yield variability}

Simulated sunflower yield ranges were remarkably sensitive to regional characteristics, which are associated with climate (Figure 4) and soil characteristics (Table 2). Northwestern locations had higher yields for most of the simulated sowing periods (Figure 5). The differences among regions can reach nearly $1,850 \mathrm{~kg} \mathrm{ha}^{-1}$ when sunflower is sown in Oct (Figure $5 \mathrm{C}$ ) which is the optimal date for most of the locations studied. For the northeastern part of Minas Gerais, which is known for the insufficient rainfall during most of the year (Figure 4), sowing dates are often the only strategy available for farmers to maximize crop production by reducing the

Table 5 - Observed and simulated sunflower yields and development stages (days after planting - DAP) followed by statistical indicators obtained for model validation.

\begin{tabular}{|c|c|c|c|c|c|c|c|}
\hline & \multicolumn{3}{|c|}{ Observed } & \multicolumn{2}{|c|}{ Simulated } & \multicolumn{2}{|c|}{ Statistics } \\
\hline & $\mathrm{N}$ & Mean & St.dev. & Mean & St.dev. & RMSE & ME \\
\hline \multicolumn{8}{|l|}{ E122 } \\
\hline First anthesis (DAP) & 8 & 51 & 7 & 55 & 3 & 14.2 & -0.3 \\
\hline $\begin{array}{l}\text { Physiological } \\
\text { maturity (DAP) }\end{array}$ & 5 & 80 & 8 & 93 & 8 & 18.7 & -3.9 \\
\hline $\begin{array}{l}\text { Yield }\left(\mathrm{kg} \mathrm{ha}^{-1}\right) \\
\text { H358 }\end{array}$ & 11 & 1615 & 753 & 1638 & 675 & 14.2 & 0.9 \\
\hline First anthesis (DAP) & 16 & 57 & 7 & 63 & 4 & 13.7 & -0.5 \\
\hline $\begin{array}{l}\text { Physiological } \\
\text { maturity (DAP) }\end{array}$ & 9 & 93 & 13 & 105 & 10 & 19.5 & -1.2 \\
\hline Yield $\left(k g h^{-1}\right)$ & 15 & 2072 & 730 & 2209 & 707 & 12.0 & 0.9 \\
\hline
\end{tabular}

risk of crop failures. In this region the negative effect of the weather, associated with limited rainfall (up to 50 $\%$ lower than in northwestern locations), is further exacerbated by the relatively large concentration of sandy soils as compared with the northwestern part of the state (Figure 2). This feature reduces soil water availability, thus resulting in unfavourable crop growth conditions.

With the rainy season for most of the selected locations starting between the second half of Oct and the first half of Nov, crop yield tends to reach its peak when sowing during this period (Figure 5C, D). Sowing sunflower in Aug resulted in low yields across the whole region, with less than $1,150 \mathrm{~kg} \mathrm{ha}^{-1}$ (Figure 5A). There is an increase in crop yields when sunflower is sown after Sept as a response to increased rainfall, reaching up to $1,125 \mathrm{~kg} \mathrm{ha}^{-1}$ in the northern, and up to $1,600 \mathrm{~kg}$ $\mathrm{ha}^{-1}$ in the southern part of the region studied (Figure $5 B)$. From sowing dates after the end of Nov a clear pattern could be identified with sunflower yields decreasing from the northwestern to the northeastern areas (Figure 5E-G). Planting dates after Feb resulted in uniform and low sunflower yields across the whole region (Figure $5 \mathrm{H})$. In this period, irrigation becomes the only strategy that can increase sunflower yield by over $4,000 \mathrm{~kg} \mathrm{ha}^{-1}$ (Figure 6). However, opportunities associated with water management have to be assessed against implementation (irrigation) and production costs.

\section{Genotype and crop management}

Besides regional yield variability, there was also a consistent difference between sunflower yields when the two genotypes were compared under different growth conditions (Figure 6). The hybrid performed better for

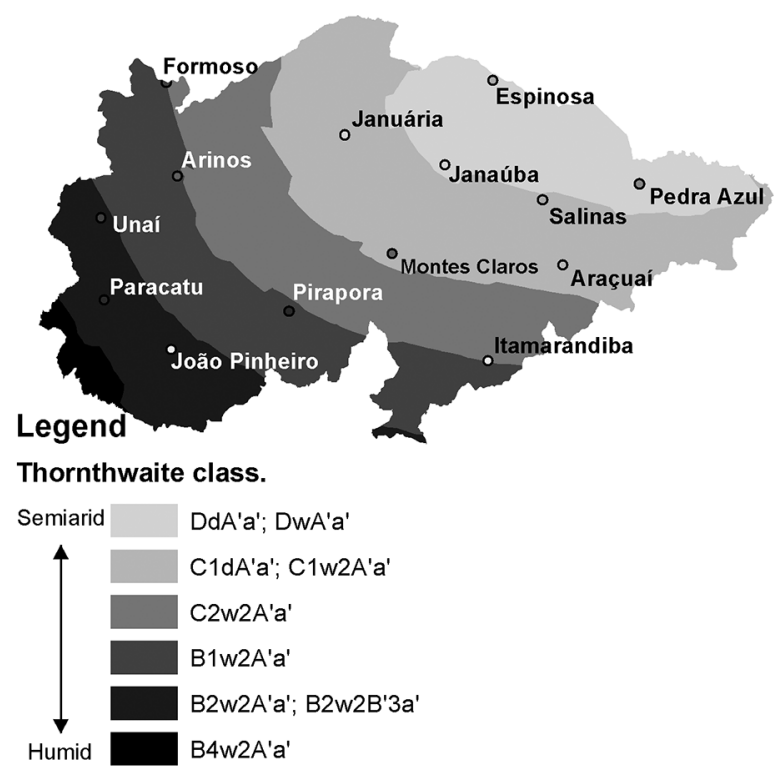

Figure 4 - Thornthwaite (1948) climate classification of the northern region of the state of Minas Gerais, Brazil. 


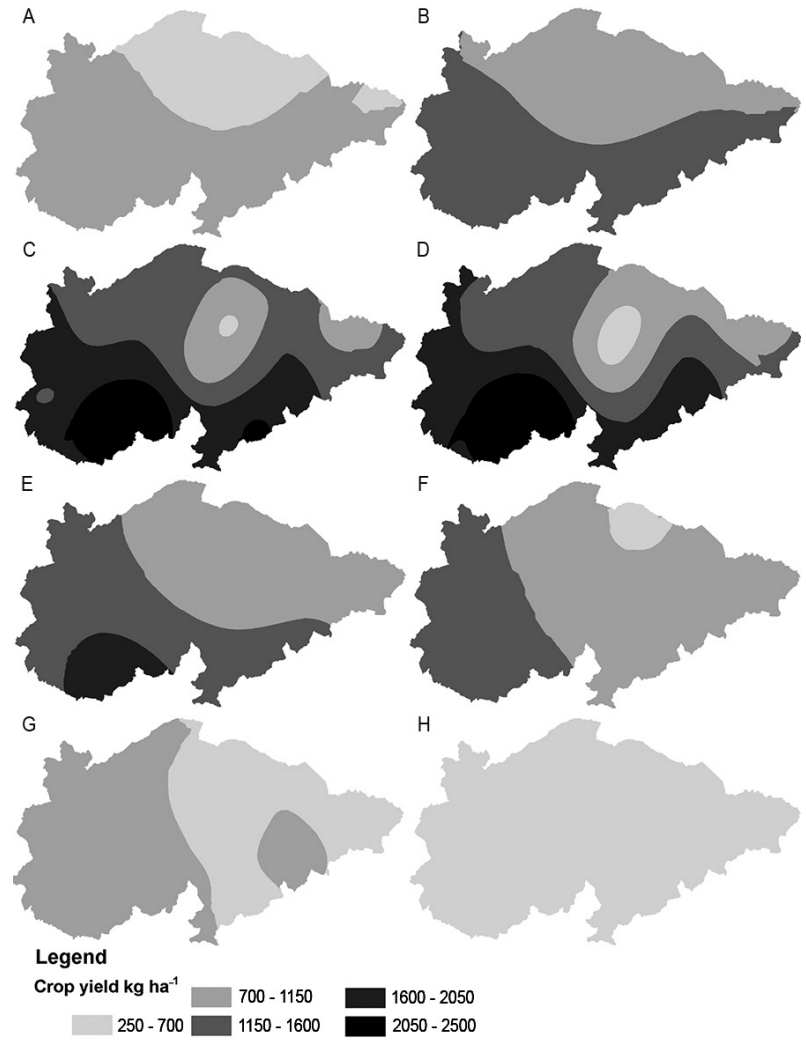

Figure 5 - Water- and nitrogen-limited sunflower average yield (31 years) in the northern region of the state of Minas Gerais, Brazil, for different sowing dates: A - Aug 23; B - Sept 22; C - Oct 27; D - Nov 24; E - Dec 22; F - Jan 26; G - Feb 23; and H - Mar 30, for $\mathrm{E} 122$ and $\mathrm{H} 358$ genotypes.

most of the tested sowing periods, except for periods with substantial water constraints, mainly at the end of the rainfall season when both cultivars performed similarly. When water and nitrogen are non-limiting (potential growth conditions) the hybrid genotype performed better throughout the entire period of simulation (Figure 6). These findings agree with the literature which indicates better performance of sunflower hybrid genotypes in Minas Gerais and other Brazilian regions.

Sunflower yields respond to higher levels of fertiliser (i.e. nitrogen) applications with an increase in crop yield from 1,000 and $1,750 \mathrm{~kg} \mathrm{ha}^{-1}$, under waterand nitrogen-limited conditions, and to 2,250 and 3,000 $\mathrm{kg} \mathrm{ha}{ }^{-1}$, under water-limited conditions, for E122 and H358, respectively (Figure 6). Maximum yields were obtained under potential conditions with sunflower yields achieving 4,250 kg ha ${ }^{-1}$ for the hybrid genotype when sown between Oct and Nov (Figure 6).

Irrigation could be a key factor in improving sunflower yields in the northeastern region of the state of Minas Gerais. In fact, there are some locations, such as Janaúba and Januária in the east with high radiation levels that can perform better in terms of sunflower yield

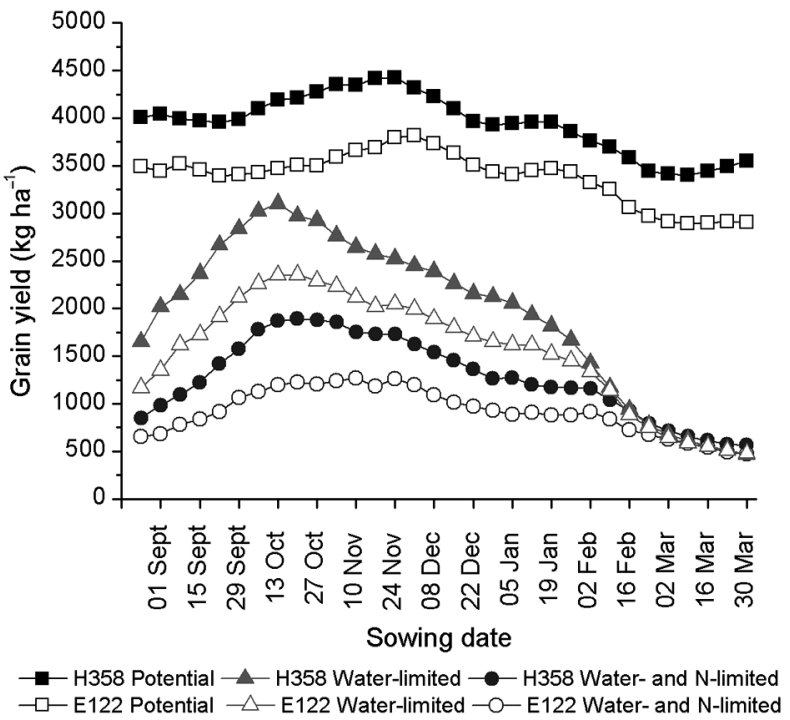

Figure 6 - Simulated sunflower average yields (31 years) under water- and nitrogen-limited, water-limited, and potential conditions, for different sowing dates, considering the data of the 14 locations in northern region of the state of Minas Gerais, Brazil.

than those in the northwestern region, such as Unaí and Paracatu (Figure 7). This is because in the absence of growth-limiting and reducing factors (biotic: weed, pest, disease; and abiotic: pollution, toxicity), growth-defining factors determine maximum production (Ittersum et al., 2003). However, water is frequently a scarce and expensive resource (Postel et al., 2001). Thus, the economic feasibility of irrigated systems is often limited to high value added crops such as vegetables and fruits. In a current irrigation project in the North of Minas Gerais state, traditional bulk crops such as maize, beans (Phaseolus vulgaris L.), cassava (Manihot esculenta Crantz) and rice (Oryza sativa), account for only $20 \%$ of the irrigated area, while vegetables and fruits, mainly banana (Musa spp.), cover nearly $70 \%$ of the total irrigated area.

\section{Local and inter-annual yield variability}

Although sunflower has been regarded as a promising crop in the light of the biodiesel policy; it is still uncertain whether it will become a sustainable option for farmers, especially in more dry regions.

Simulated sunflower yields for Pedra Azul, one of the driest locations in the database (Figure 4), with just short of $900 \mathrm{~mm}$ average annual rainfall, shows that the opportunity to maximize yields is constrained to a short sowing period, which extends from Oct $6^{\text {th }}$ to $20^{\text {th }}$, especially for the H358 genotype (Figure 8). The simulated yields for this sowing period are $1,500 \mathrm{~kg} \mathrm{ha}^{-1}$ for $\mathrm{H} 358$ and $1,000 \mathrm{~kg} \mathrm{ha}^{-1}$ for E122. Although there is still a large variability of yields over the years due to rainfall distribution (from 600 to 3,400 kg ha-1; Figure 8), sunflower yield tend to decrease in all other sowing periods. Potential conflicts could emerge as this optimum period also 


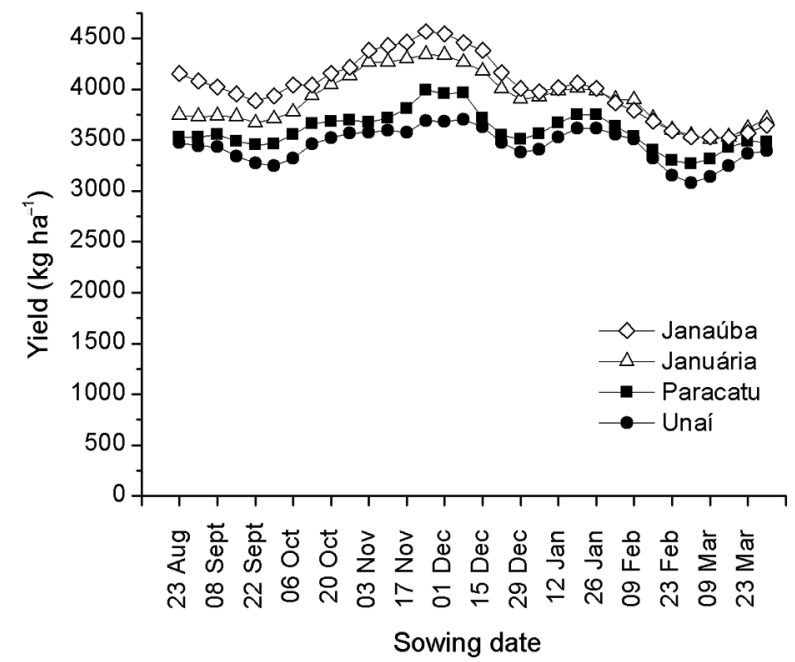

Figure 7 - Potential sunflower average yields (31 years) for Paracatu and Unaí, in the northwestern, and for Janaúba and Januária, in the northeastern regions of the state of Minas Gerais, Brazil.
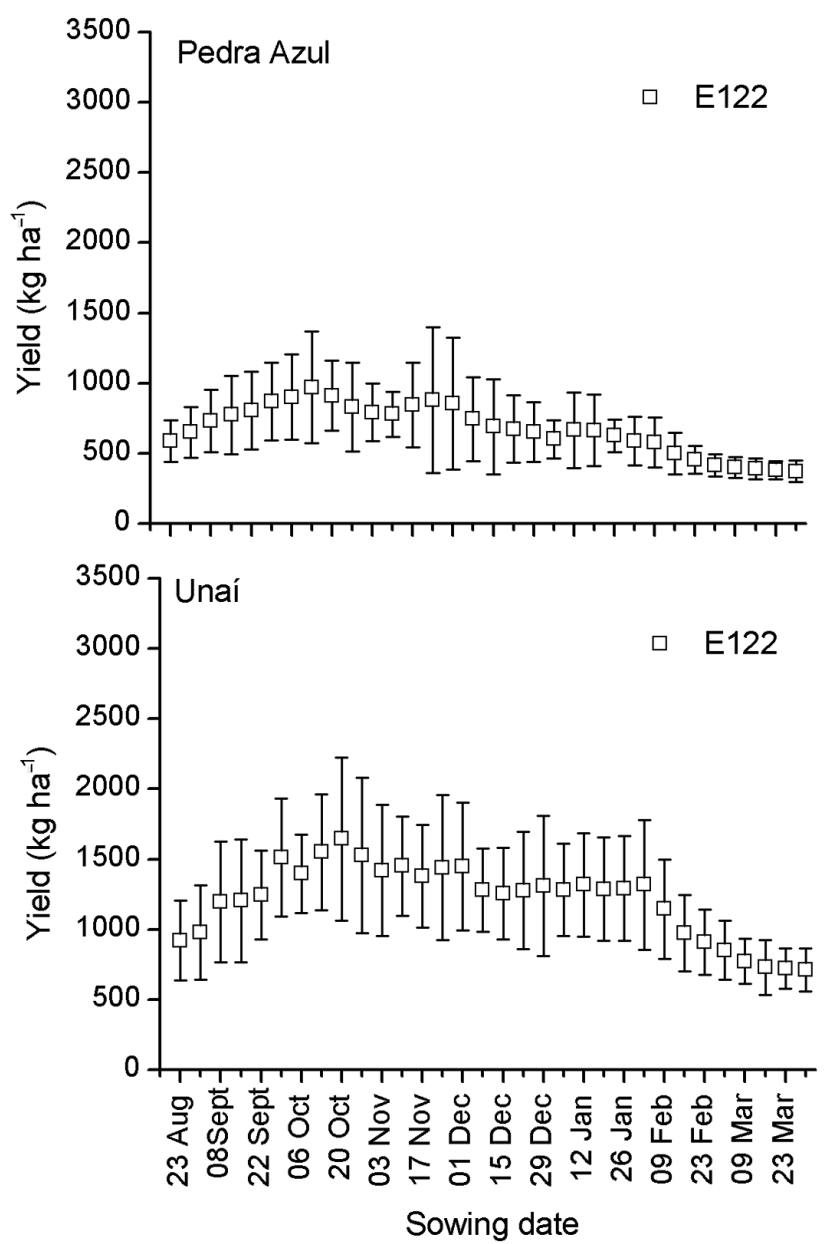

coincides with the sowing of current crops (e.g. maize and beans). Family farmers, who are targeted by the biodiesel policy in the northern region of Minas Gerais, are often resource constrained (i.e. land, labour and cash) (Leite et al., 2013). Thus, their engagement in the production of sunflower for the biodiesel industry could lead to potential competition with current crops with further impacts on food and feed production (Florin et al., 2012). Furthermore, the availability of quantitative studies which systematically compare the economic and environmental sustainability of biodiesel crops against current ones is still limited.

Unaí has a humid climate (Figure 4) with a more favourable rainfall level and distribution $1 \approx 1,400 \mathrm{~mm}$ average annual rainfall) than Pedra Azul. This location is one of the most important agricultural regions in the state, where soybean (Glycine max L.) stands out as the one of major value. Despite some yield variation, the opportunity to maximize sunflower grain yield in Unaí is clearly greater than in Pedra Azul, if a hybrid geno-

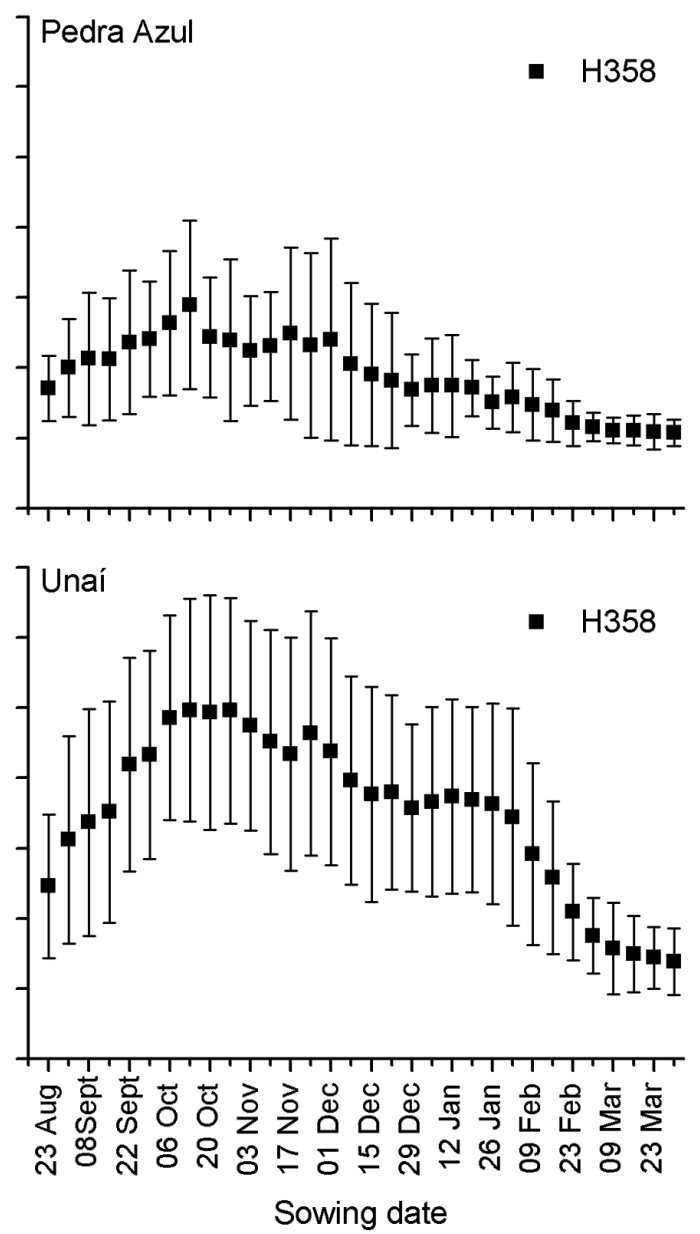

Figure 8 - Water- and nitrogen-limited sunflower yields for the genotypes H358 and E122 in Pedra Azul (northeast) and Unaí (northwest), in the state of Minas Gerais, Brazil. Dots represent the averages $(n=31)$ and bars the standard deviations. 
type is cultivated. Optimal yields could be attained in a sowing period between the beginning of Oct to the end of Nov, that would reach 2,500 $\mathrm{kg} \mathrm{ha}^{-1}$ for the H358 genotype (Figure 8). Although the economic competitiveness of sunflower with soybean is still questionable, there seems to be room for the inclusion of sunflower in a rotation with current crops or in double cropping systems. In the case of the latter, sunflower could be cultivated as a second crop following early planted soybean or maize. The success of such an arrangement, however, relies on the combination of short cycle cultivars which allow sunflower to be sown until mid-February, when yields of about $1,300 \mathrm{~kg} \mathrm{ha}^{-1} \mathrm{can}$ be achieved with the hybrid genotype under water- and nitrogen-limited conditions.

Short cycle sunflower genotypes such as E122 are often claimed to be the best option for double cropping systems, being less likely to be affected by the shrinking water availability towards the end of the rainy season. However, the simulations for $\mathrm{H} 358$, had higher yields, between 50 and $100 \mathrm{~kg} \mathrm{ha}^{-1}$, in both locations in the late sowings, when rainfall decreases significantly (Figure 8). This result does not rule out the impact of the crop cycle, which can indeed be an effective strategy for crop production in short rain periods (Bazza, 2001), but highlights that, for the simulated growth conditions and genotypes, such an advantage was not observed.

\section{Conclusions}

The OILCROP-SUN crop model was effective in simulating sunflower yields for the northern region of Minas Gerais. However, simulations of the leaf area index, above ground biomass and crop phenology should be interpreted with caution. Simulated sunflower yields presented a spatial pattern across the northern region of Minas Gerais, with higher yields attained in the northwestern area where the sowing window to reach optimal crop yield is larger than in the northeast. The hybrid genotype (H358) had higher yields for all simulated sowing dates, locations and growth conditions than the conventional cultivar (E122).

\section{Acknowledgements}

We thank WOTRO Science for Global Development for providing financial support to the project "Biomass for fuel: opportunity or threat to food and feed security?" We also acknowledge the support of Dr. José Carlos Fialho de Resende and others from the Minas Gerais Agriculture Research Company (EPAMIG) for field support and sunflower experimental information. Furthermore, we thank Dr. Rafael de Ávila Rodrigues (Federal University of Viçosa), Ir. Joost Wolf (Wageningen University), Prof. Francisco Villalobos (University of Córdoba) and Prof. Gerrit Hoogenboom (Washington State Universityl for providing useful insights during different steps of model calibration and evaluation. We finally thank the two anonymous reviewers for their thorough reviews which helped to improve this manuscript.

\section{References}

Allen, R.G.; Pereira, L.S.; Raes, D.; Smith, M. 1998. Crop Evapotranspiration: Guidelines for Computing Crop Water Requirements. FAO, Rome, Italy. (Irrigation and Drainage Paper, 56).

Bazza, M. 2001. Inferences of a Drought Mitigation Action Plan. FAO, Rome, Italy.

Boogaard, H.L.; Diepen, C.A. van; Rotter, R.P.; Cabrera, J.C.M.A.; Laar, H.H. van 1998. User Guide for the WOFOST 7.1 Crop Growth Simulation Model and WOFOST Control Center 5.1. Alterra, Wageningen, The Netherlands.

Bouman, B.A.M.; Keulen, H. van; Laar, H.H. van; Rabbinge, R. 1996. The "School of de Wit" crop growth simulation models: a pedigree and historical overview. Agricultural Systems 52: 171-198.

Connor, D.; Sadras, V. 1992. Physiology of yield expression in sunflower. Field Crops Research 30: 333-389.

Doorenbos, J.; Kassan, A.H. 1994. Water effect on crop productivity. = Efeito da água no rendimento das culturas. UFPB, Campina Grande, PB, Brazil. (in Portuguese).

Dosio, A.A.; Rey, H.; Lecoeur, J.; Izquierdo, N.G.; Aguirrezábal, L.A.N.; Tardieu, F.; Turc, O. 2003. A whole-plant analysis of the dynamics of expansion of individual leaves of two sunflower hybrids. Journal of Experimental Botany 54: 2541-2552.

Florin, M.J.; Ittersum, M.K. van; Ven, G.W.J. van de. 2012. Selecting the sharpest tools to explore the food-feed-fuel debate: sustainability assessment of family farmers producing food, feed and fuel in Brazil. Ecological Indicators 20: 108-120.

Goyne, P.J.; Schneiter, A.A. 1988. Temperature and photoperiod interactions with phenological development of sunflower. Agronomy Journal 80: 777-784.

Hall, A.J.; Connor, D.J.; Whitfield, D.M. 1989. Contribution of pre-anthesis assimilates to grain-filling in irrigated and waterstressed sunflower crops. I. Estimates using labelled carbon. Field Crops Research 20: 95-112.

Hall, A.; Connor, D.; Sadras, V. 1995. Radiation-use efficiency of sunflower crops: effects of specific leaf nitrogen and ontogeny. Field Crops Research 41: 65-77.

Hazell, P.B.R.; Norton, R.D. 1986. Mathematical programming for economic analysis in agriculture. Macmilllan, London, UK.

Hoogenboom, G. 2000. Contribution of agrometeorology to the simulation of crop production and its application. Agricultural and Forest Meteorology 103: 137-157.

Instituto Brasileiro de Geografia e Estatística [IBGE]. 1986. Radambrasil. Natural Resource Assessment. = Levantamento de Recursos Naturais. IBGE, Rio de Janeiro, RJ, Brazil (in Portuguese).

Instituto Nacional de Meteorologia [INMET]. 2012. Meteorological database for research studies. $=$ Banco de dados meteorológicos para ensino e pesquisa (BDMEP). Available at: http://www. inmet.gov.br/portal/index.php? $\mathrm{r}=\mathrm{bdmep} / \mathrm{bdmep}$ [Accessed July 10, 2012] (in Portuguese). 
International Benchmark Sites Network for Agrotechnology Transfer [IBSNAT]. 1993. The IBSNAT Decade: Ten Years of Endeavour at the Frontier of Science and Technology. University of Hawaii, Honolulu, HI, USA.

Ittersum, M.K. van; Leffelaar, P.A.; Keulen, H. van; Kropff, M.J.; Bastiaans, L.; Goudriaan, J. 2003. On approaches and applications of the Wageningen crop models. European Journal of Agronomy 18: 201-234.

Jacomine, P.K.T.; Cavalcanti, A.C.; Foriga, R.A.; Silva, F.B.R.; Burgos, N.; Medeiros, L.A.R.; Lopes, O.P.; Melo Filho, H.F.R.; Pessoa, S.G.P.; Lima, P.C. 1979. Exploratory Assessment of Soils in the North of Minas Gerais (Area Managed under SUDENE). = Levantamento Exploratório - Reconhecimento de Solos do Norte de Minas Gerais (Área de Atuação da SUDENE). Embrapa/SNLCS, Recife, PE, Brazil. (Boletim Técnico, 60) (in Portuguese).

Jamieson, P.D.; Porter, J.R.; Wilson, D.R. 1991. A test of the computer simulation model ARCWHEAT1 on wheat crops grown in New Zealand. Field Crops Research 27: 337-350.

Jones, J.W.; Hoogenboom, G.; Porter, C.H.; Boote, K.J.; Batchelor, W.D.; Hunt, L.A.; Wilkens, P.W.; Singh, U.; Gijsman, A.J.; Ritchie, J.T. 2003. The DSSAT cropping system model. European Journal of Agronomy 18: 235-265.

Laar, H.H. van; Goudriaan, J.; Keulen, H. van. 1997. SUCROS97: Simulation of Crop Growth for Potential and Water-Limited Production Situations. C. T. de Wit Graduate School for Production Ecology and Resource Conservation, Wageningen, The Netherlands.

Leite, J.G.D.B.; Bijman, J.; Giller, K.; Slingerland, M. 2013. Biodiesel policy for family farms in Brazil: One-size-fits-all? Environmental Science \& Policy 27: 195-205.

Lizaso, J.I.; Batchelor, W.D.; Westgate, M.E.; Echarte, L. 2003. Enhancing the ability of CERES-Maize to compute light capture. Agricultural Systems 76: 293-311.

Loague, K.; Green, R.E. 1991. Statistical and graphical methods for evaluating solute transport models: overview and application. Journal of Contaminant Hydrology 7: 51-73.

Lu, C.; Fan, L. 2013. Winter wheat yield potentials and yield gaps in the north China Plain. Field Crops Research 143: 98-105.

Postel, S.; Polak, P.; Gonzales, F.; Keller, J. 2001. Drip irrigation for small farmers. Water International 26: 3-13.

Pereira, M.; Trapani, N.; Sadras, V. 1999. Genetic improvement of sunflower in Argentina between 1930 and 1995. II. Phenological development, growth and source-sink relationship. Field Crops Research 63: 247-254.

Pringle, M.J.; McBratney, A.B.; Cook, S.E, 2004. Field-scale experiments for site-specific crop management. Part II. A geostatistical analysis. Precision Agriculture 5: 625-645.
Rinaldi, M.; Losavio, N.; Flagella, Z. 2003. Evaluation and application of the OILCROP-SUN model for sunflower in southern Italy. Agricultural Systems 78: 17-30.

Robinson, R.G. 1971. Sunflower phenology: year, variety and date of planting effects on day and growing degree-day summations. Crop Science 11: 635-638.

Rodrigues, R.A.; Pedrini, J.E.; Fraisse, C.W.; Fernandes, J.M.C.; Justino, F.B.; Heinemann, A.B.; Costa, L.C.; Vale, F.X.R. 2013. Utilization of the cropgro-soybean model to estimate yield loss caused by Asian rust in cultivars with different cycle. Bragantia 71: 308-317.

Sadras, V.O.; Hall, A.J. 1988. Quantification of temperature, photoperiod and population effects on plant leaf area in sunflower crops. Field Crops Research 18: 185-196.

Sadras, V.; Connor, D.; Whitfield, D. 1993. Yield, yield components and source-sink relationships in water-stressed sunflower. Field Crops Research 31: 27-39.

Schneiter, A.A.; Miller, J.F. 1981. Description of sunflower growth stages. Crop Science 21: 901-903.

Thornthwaite, C.W. 1948. An approach toward a rational classification of climate. Geographical Review 38: 55-94.

Todorovic, M.; Albrizio, R.; Zivotic, L.; Saab, M.T.A.; Stöckle, C.; Steduto, P. 2009. Assessment of AquaCrop, CropSyst and WOFOST models in the simulation of sunflower growth under different water regimes. Agronomy Journal 101: 509-521.

Trapani, N.; Hall, A.J.; Sadras, V.O.; Vilella, F. 1992. Ontogenetic changes in radiation use efficiency of sunflower (Helianthus annuus L.) crops. Field Crops Research 29: 301-316.

Universidade Federal de Viçosa; Fundação Centro Tecnológico de Minas Gerais; Universidade Federal de Lavras; Fundação Estadual do Meio Ambiente. 2010. Soil Map of Minas Gerais State. = Mapa de solos do Estado de Minas Gerais. Belo Horizonte, 49p. (in Portuguese).

Vieira, S.R.; Gonzalez, A.P. 2003. Analysis of the spatial variability of crop yield and soil properties in small agricultural plots. Bragantia 62: 127-138.

Villalobos, F.; Ritchie, J. 1992. The effect of temperature on leaf emergence rates of sunflower genotypes. Field Crops Research 29: $37-46$.

Villalobos, F.J.; Hall, A.J.; Ritchie, J.T.; Orgaz, F. 1996. OILCROPSUN: a development, growth, and yield model of the sunflower crop. Agronomy Journal 88: 403-415.

Whitfield, D.M.; Connor, D.J.; Hall, A.J. 1989. Carbon dioxide balance of sunflower (Helianthus annuus L.) subjected to water stress during grain-filling. Field Crops Research 20: 65-80. 